\title{
Nutritional Studies to Evaluate the Productivity and Quality of Preserved New Variety of Hybride Maize Silage on : \\ 1- Milk Production and Its Composition,Some Rumen and Blood Parameters, Feed Utilization and Economical Efficiency in Lactating Zaribi Goats . \\ Saleh, M. R. M.
}

Animal Production Research Institute, Agriculture Research Center, Dokki , Egypt .

\begin{abstract}
This experiment was carried out to study the effect of a new variety of hybrid El-Ryanah maize x El-Shamia maize as silage alone or mixture with berseem $(1: 1)$ on milk production , milk constituents, rumen microorganisms , hematological parameters and economic efficiency by lactating zaribi goats.Twenty four lactating zaribi goats 30 month old and weighed $40.93 \pm 0.36 \mathrm{~kg}$ were divided into three similar groups and randomly assigned to three experimental diets. Animals in all groups were fed a concentrate feed mixtures(CFM) to cover $50 \%$ of protein diet according to (NRC,1989) requirement. Addition to ad libitum supplement of hybrid maize silage alone or mixtures with berseem, where $100 \%$ berseem silage was offered to group $\left(\mathrm{T}_{1}\right), 100 \%$ hybrid maize silage for group $2\left(\mathrm{~T}_{2}\right)$ and $50 \%$ berseem silage $+50 \%$ hybrid maize silage for group $\mathrm{g}_{3}\left(\mathrm{~T}_{3}\right)$. The experiment lasted for 120 days (Lactating period).The results obtained indicated that (T2) characterized by high OM , CP and NFE \% and low of DM, EE , CF and Ash \% than those of T1 and T3 rations. While ,mixture of hybrid maize and berseem silage (T3) generally had higher values of DM and Ash. At the same time, T1 ration recorded higher values of EE and CF and lower values of NFE \% than those of T2 ration .However, data of fiber fractions clearly showed that $\mathrm{T}_{1}$ ration had higher values of $\mathrm{NDF}$, ADF, celluloses and ADL ( $31.5,23.7,8.20$ and 15.50\% respectively). Moreover, the concentration of fiber and fiber fractions were negatively related to quality because forages had higher fiber and less available energy and are consumed with a few amounts by goats than that with low fiber content. Meanwhile, the average DM as $\mathrm{g} / \mathrm{kg} \mathrm{BW}$ or w ${ }^{0.75}$ decreased with $\mathrm{T}_{2}$ (38.2.and 97.1) compared with $\mathrm{T}_{1}$ (39.9 and 101.5) and $\mathrm{T}_{3}$ (4.16 and 105.3 respectively).Feed conversion as DM and CP(intake / $\mathrm{kg}$ milk yield) were better with $\mathrm{T}_{2}(1.14$ and 237$)$ and $\mathrm{T}_{1}(1.43$ and 245$)$ compared with $\mathrm{T}_{3}(1.34$ and 239 respectively).Whereas, digestion coefficients of $\mathrm{T}_{2}$ ration recorded significantly $(\mathrm{p}<0.05)$ the highest digestibility coefficients of $\mathrm{CP}, \mathrm{CF}, \mathrm{EE}, \mathrm{NFE}$ and GE ( $76.94,64.91,74.82,74.13$ and 66.25 respectively) while, $\mathrm{T}_{3}$ had higher values of DM , OM and lower of CP, EE, CF and GE ( $70.62,74.32,74.91,61.88,72.94,72.24$ and 64.17 respectively) and the lowest values had detected with $\mathrm{T}_{1}$ ration ( $68.97,71.37,75.28,63.17,72.56,71.61$ and 63.31 respectively ). As milk yield , the results showed that the higher actual daily milk yield (ADMY) and 4\% fat corrected milk yield (FCMY)were obtained with of dairy zaribi goats fed tested rations T2 (1.390 , $1.350 \mathrm{~kg} / \mathrm{d}$ respectively ) than of those fed $\mathrm{T} 1(1.168,1.119 \mathrm{~kg} / \mathrm{d}$,respectively) and the lowest values were recorded with $\mathrm{T} 3$ ration (1.274 and 1.206 respectively). Moreover,T2 ration were significantly $(\mathrm{p}<0.05)$ increase of fat, total solid, total nitrogen, lactose and Net Energy $(3.81,13.40,7.30,5.31$ and 1.60 respectively), but it recorded the lowest values with \% protein and solid nonfat (3.38 and 9.59 respectively) than those of other experimental treatments. Blood hematology explain that $\mathrm{T} 3 \mathrm{ration}$ had the lowest values of RBC, hemoglobin, $\mathrm{MCV}, \mathrm{MCH}, \mathrm{MCHC}$, total protein , globulin , serum glucose and urea-N comparison of T1 and $\mathrm{T} 2$ rations. In addition, the results of economic efficiency were clearly that goats fed $\mathrm{T} 2$ ration had the highest value ( 12.03 $\%$ ) and $\mathrm{T} 3$ ration ( 6.65$)$, whereas $\mathrm{T} 1$ ration had the lowest value.
\end{abstract}

Keywords : dairy zaribi goats , hybrid maize silage , milk yield and milk constitutes . some hematological parameters , rumen ctivity .

\section{INTRODUCTION}

In Egypt Animals are suffering from shortage of feeds especially during summer season. Animal feeding this period depend on grains, concentrate feed mixtures and agriculture residues. The rising costs of feed in particularly, grains and protein supplemented have led to significant increase in animal feed cost during recent years. Forages are usually the cheapest ingredients in animal ration .small ruminants as well as sheep and goats are important domestic animals all over the world , because of their adaptability to different environmental conditions and utilizing poor quality forages and feed stuffs . Maize in Egypt is considered the main summer forage in the sheep and goats diets so that occupies large area of available cultivated lands. Maize plant silage is a well digestible and palatable high quality forage crop and mainly used as silage high contain of energy for dairy animals particularly with small dairy animals . Different starch sources, optimizes the growth of rumen microbial and influences the rate population of microbial protein synthesis, nitrogen utilization and production of volatile fatty acids (Jalce et al., 2009).
Preserving green forages on the form of silage for minimal loss of nutritive value due to anaerobic fermentation of soluble carbohydrates to organic acids. (Adogla and Aganga , 2000) found that supplying the right amount of corn silage had the higher improved production of herds. Corn silage can be an economic source of nutrients for dairy animals, particularly on large farms where feeding can be mechanized (Olker $e t$ al., 2009) and ( Wrobel, 2009) explained that microorganisms gas play important roll in silage to improve fermentation which evident by a rapid decline in $\mathrm{pH}$. increase of lactic acid and decreased ammonia nitrogen content. Also they reported that, silage fermentation has a major effect on feed intake, nutrients utilization and milk production of ruminants. ( Huhtanen et al., 2003), registration that changes in milk composition will be reflected on the nutritional and economic values of sheep and goat's milk of other dairy products . Constructively, ( Nkosia et al., 2011) observed that intake and digestibility of organic matter, crude protein, dry matter and fiber in addition to nitrogen retention were improved when small ruminant fed bacterial inoculated corn silage. 


\section{MATERIALS AND METHODS}

Twenty four lactating Zaribi goats averaging $40.93 \pm 0.36 \mathrm{~kg} \mathrm{LBW}$ with nearly 30 months as age were randomly chosen and divided into three similar groups ( 8 in each ) according to their body weight. The aim of the trial was to assess the effect of feeding a new hybrid variety of hybrid El-Raianah $\mathrm{x}$ El-Shamia maize on the form of silage on feed consumption ,milk production and milk constituents, and some blood parameters, rumen microorganisms, and economic efficiency by lactating zaribi goats. All does were of good productive and performance, the animals were housed in separated pens under nearly similar environmental condition.

\section{Animals feeding}

All animals groups were fed a concentrate feed mixtures (CFM) to cover fifty $\%$ of protein requirement. Addition to ad libitum supplement of hybrid maize silage alone or with berseem mixture where, $100 \%$ berseem silage offered to $\operatorname{group}_{1}\left(\mathrm{~T}_{1}\right), 100 \%$ hybrid maize silage group $2\left(\mathrm{~T}_{2}\right)$ and $50 \%$ berseem silage $+50 \%$ hybrid maize silage for group ${ }_{3}\left(\mathrm{~T}_{3}\right)$. Rations were offered twice daily at 8 a.m. and 4 p.m. while water was offered freely. The CFM and feedstuffs were analyzed according to (AOAC , 2005).Contents of neutral detergent fiber (ADF) and acid detergent fiber were analyzed using Goering and (Van Soest ,1991) method. The chemical compositions of experimental diets are recorded in Table (1).The quantity of offered feed and the residual diet was measured to determine feed intake during lactation periods. Milk production was assessed individually byweekly. Concentrate feed mixture (CFM) consisted of $25 \%$ undecortecated cottonseed meal , 38.5\% yellow corn, $10 \%$ soybean meal , $20 \%$ wheat bran, 3\% molasses, $2.5 \%$ limestone and $1.0 \%$ common salt. Gross energy (GE) was calculated according to (Blaxter ,1966). Digestion trials

Animals of digestion trials were feeding individual. three digestion trials were conducted(3 animals in each).The digestion stages were two weeks considered as preliminary period followed by seven days collection period .Urine and feces samples were collected daily . Solution of $20 \% \mathrm{H}_{2} \mathrm{SO}_{4}$ was added to representative urine samples .Samples of tested feedstuffs were taken at the beginning, middle and collection end period. The samples were analyzed according to (AOAC , 2005).Body weights of all animals were recorded fortnightly during experimental period.

Milk yield

New-born lambs were kept with their mothers till weaning, except during time of milk yield recording. During suckling period, milk yield was recorded by weekly for all does while separating kids from mothers. Samples were taken when udder was milked and yield was corrected for $4 \%$ fat correction milk (FCM) using the next formula $=0.265 \mathrm{x}$ milk yield $(\mathrm{kg})+10.5 \mathrm{x}$ fat yield $\mathrm{x}$ milk yield $(\mathrm{kg})$ as stated by ( Rafat and Saleh ,1962).Milk samples from consecutive evening and morning milking were taken and mixed in proportion to yield.

\section{Milk samples and composition}

Does in all tested groups and during suckling their kids the milk samples were composed and analyzed for chemical composition according to Bradley et al.(1992).Yield of 4\% FCM were computed .Fat , protein, lactose and total solid of milk were determined . Rumen fermentation study

Three trials of digestion ( 3 animal in each ) were used to determine of change in the $\mathrm{pH}$ and total volatile fatty acid (TVFAs) and nitrogenous constituents of rumen liquor at 0,3 and $6 \mathrm{hr}$. samples were studied by collecting $250 \mathrm{ml}$ of rumen liquor from each animal, using a stomach tube(Gastric tube) employing suction( Lane et al.,1968).The rumen liquor was immediately brought to the laboratory and strained through three layers of cheese cloth. The $\mathrm{pH}$ was determined immediately using a digital $\mathrm{pH}$ analyzer (ELICO LI 614).sample of rumen liquor were analyzed for total nitrogen(TN),NH3-N concentration according to (AOAC, 2000), while the VFAS concentration was determined according to (Eadie et al. ,1967).

Blood biochemical and hematology profile

At the end of experiment $10 \mathrm{ml}$ blood was collected before feeding in hepatized test tubes through the jugular vein of lactating goats in each group. Whole blood was immediately used for hematological estimation .Plasma was separated from an others blood samples by centrifugation at $3500 \mathrm{rpm}$ for 20 minutes whereas a part was used for enzyme determination, the other part was kept frozen at $-20^{\circ} \mathrm{C}$ until other biochemical analysis as well as red blood cells (RBC), hemoglobin, hematocrit, mean cell volume (MCV), mean cell hemoglobin concentration (MCHC), platelets (PLT) and white blood cells (WBC), total protein , albumin, globulin, glucose and creatinine were determined according to (Weichselbaum ,1989) and ( Drupt ,1974) .

\section{Feed conversion}

Feed intake were recorded biweekly, the experiment lasted for 120 days. The feed conversion was calculated as the amounts of dry matter (DM), total digestible nutrients (TDN) or digestible crud protein (DCP) required to produce $1 \mathrm{~kg} 4 \%$ fat correction milk (FCM ).

\section{Minerals contained}

The aching and minerals of rations as well as , calcium $(\mathrm{Ca})$, phosphorus $(\mathrm{P})$, magnesium $(\mathrm{Mg})$, sodium $(\mathrm{Na})$, potassium $(\mathrm{K})$, Zinc $(\mathrm{Zn})$, ferrous $(\mathrm{Fe})$, manganese $(\mathrm{Mn})$, and copper $(\mathrm{Cu})$ were determined according to work (Hoek et al.,1988) .

\section{Economic efficiency}

Economic efficiency for gain production expressed as the daily price of $\mathrm{kg}$ milk , feed cost of $\mathrm{kg}$ milk and cost of feed consumed, Whereas, price of ton concentrate feed mixture $=3000 \mathrm{LE} / \mathrm{ton}, \mathrm{kg}$ milk $=4$ LE , hybrid maize $(\mathrm{HSRS})=180 \mathrm{LE} /$ ton , berseem silage $=240 \mathrm{LE} /$ ton , mixture of hybrid maize $\mathrm{x}$ berseem silage $=210 \mathrm{LE} /$ ton and rice straw $=100 \mathrm{LE} /$ ton (according to price of 2015) . 


\section{Statistical analysis}

All numerical data obtained were statistical analyzed by SAS (2009) procedures for personal computer. When F-test was positive, least significant differences Duncan (1955) within program SPSS was done to determine the degree of significance between means.

\section{Results and Discussion}

Chemical compositions of concentrate mixture and silages

Chemical compositions of berseem silage (BS),hybrid Ryanah x Shamia(HRS) and Ryanah x Shamia + berseem silage (HRSXBS) were calculated for composition of different rations and the data are presented in Table (1). Data clearly showed that, HRS (T2) characterized by higher values of $\mathrm{OM} \mathrm{CP}$ and NFE \% and lower of DM , EE , CF and ash\% than T1 and $\mathrm{T} 3$ rations. These agreement with those reported by (Mahmoud et al .,1992), (Khinizy et al. ,1997), and( ElSayes et al.,1997).Moreover,T3 ration had higher values of DM and ash but, it lower of OM and CP than other tested groups. This data were within the normal ranges reported by (Mostafa et al.,1999). (Mohammad et al., 1999) and (Moawad et al.,2001). On the other hand , $\mathrm{T}_{1}$ ration had the higher values of NDF, ADF, Hemicelluloses ,Celluloses, and ADL and the values were $(31.5,23.7,7.8,8.2$ and 15.50 respectively ) compared to $\mathrm{T}_{2}$ and $\mathrm{T}_{3}$ rations. Meanwhile, $\mathrm{T}_{2}$ ration had lower values $(30.8,20.2,10.6,7.7$ and 12.5 for NDF, ADF, Hemicelluloses, Celluloses and ADL respectively .(Wheeler ,2003) recommended the concentrations of non-fiber carbohydrate (NFC) in lactation rations (\% of diet DM) should not bellow than 20-25\% and not more 40-45\% (NRC, 2001). Rations should never exceed $44 \%$ NFC or contained less than $15 \%$ for age NDF. In addition to ,the concentration of fiber and fiber fractions were negatively related to quality because forages higher fiber had less available energy and are consumed with a few amounts by goats than the forages with low contain of fiber (Weiss el al.,1982). Moreover,T2 ration had higher values with NDS and $\operatorname{ANDF}(69.20$ and 21.56) and lower of $\mathrm{UNDF}(9.24)$ in compassion to $\mathrm{T} 1$ and $\mathrm{T} 3$ ration.

Table 1. Chemical analysis and cell wall constituents content of the Feedstuffs ( on \% DM bases ) .

\begin{tabular}{lcccccccc}
\hline Items & & \multicolumn{3}{c}{ ingredients } & \multicolumn{3}{c}{ Experimental Rations } \\
& CFM & BS & RS & HRSS & HRSXBS & $\mathbf{T}_{\mathbf{1}}$ & $\mathbf{T}_{\mathbf{2}}$ & $\mathbf{T}_{\mathbf{3}}$ \\
\hline DM & 91,53 & 87.17 & 89.13 & 88.63 & 86.72 & 88.32 & 87.79 & 90.46 \\
OM & 90.27 & 87.41 & 87.35 & 88.91 & 88.62 & 90.69 & 90.87 & 89.83 \\
CP & 14.39 & 14.12 & 1.36 & 14.25 & 14.17 & 14.67 & 14.89 & 14.03 \\
EE & 3.27 & 2.31 & 1.45 & 2.76 & 2.27 & 2.94 & 2.54 & 2.79 \\
CF & 12.63 & 22.93 & 28.31 & 22.73 & 22.77 & 21.45 & 17.02 & 20.78 \\
NFE & 59.98 & 49.05 & 56.23 & 49.17 & 49.41 & 51.63 & 56.42 & 52.23 \\
Ash & 9.73 & 12.59 & 12.65 & 11.09 & 11.38 & 9.31 & 9.13 & 10.17 \\
NDF & 38.57 & 38.73 & 40.88 & 40.75 & 39.53 & $31.50^{\mathrm{A}}$ & $30.80^{\mathrm{B}}$ & $31.40^{\mathrm{A}}$ \\
ADF & 20.76 & 21.55 & 22.16 & 19.79 & 18.92 & $23.70^{\mathrm{A}}$ & $20.20^{\mathrm{B}}$ & $19.70^{\mathrm{B}}$ \\
Hemic. & 17.81 & 17.18 & 18.72 & 20.96 & 20.61 & $7.80^{\mathrm{A}}$ & $10.60^{\mathrm{B}}$ & $11.70^{\mathrm{B}}$ \\
Cellulo. & 12.42 & 13.16 & 14.33 & 12.17 & 10.07 & 8.20 & $7.70^{\mathrm{B}}$ & $5.10^{\mathrm{B}}$ \\
ADL & 8.34 & 8.39 & 7.83 & 7.62 & 8.85 & 15.50 & 12.50 & 14.60 \\
NFC * & 34.04 & 32.25 & 43.66 & 31.15 & 32.65 & 41.58 & 42.64 & 41.61 \\
NDS** & 61.43 & 61.27 & 59.12 & 59.25 & 60.47 & 68.50 & 69.2 & 68.60 \\
UNDF*** & 7.72 & 7.80 & 7.68 & 7.45 & 8.40 & 11.72 & 9.24 & 11.00 \\
ANDF**** & 30.85 & 30.93 & 33.20 & 33.30 & 31.13 & 19.78 & 21.56 & 20.40 \\
\hline A & & & &
\end{tabular}

$\mathbf{A}$ and $\mathrm{B}$ Means in the same row with different superscripts differ significantly at $\mathrm{P}<\mathbf{0 . 0 5}$.

* Non fibrous carbohydrate \% (NFC) $=100$ - ( CP\%+EE\%+Ash\%+NDF\% $)$, ( Calsamiglia et al., 1995).

$* *$ NDS : Neutral detergent soluble =100 - NDF. ***UNDF: Unavailable NDF= NDF X 0.01X ADLX 2.4 ( Fox et al ., 2000) .

***** ANDF Available NDF $=$ NDF - UNDF .

CFM = concentrate feed mixture , BS= berseem silage , HRSS = hybrid El-Raianah $x$ El-Shamia maize silage,

HRSXBS= hybrid El-Raianah $x$ El-Shamia maize silage $x$ berseem silage) .

\section{Minerals as macro and trace elements}

Data of minerals are presented in Table(2) .Obtained results showed macro elements of $\mathrm{T} 1$ ration were recorded the lowest values of calcium, phosphorus , magnesium and sodium $(0.46,0.41,0.16$ and 0.21 respectively) except of potassium $(\mathrm{K})$ was higher than T3 ration, At same time,T2 ration had recorded the highest values of calcium, phosphorus , magnesium , sodium and potassium $(0.84,0.71,0.25,0.33$ and 1.47 respectively). As a general rule if maize silage makes up $25 \%$ or more of a lactating goats diet it must be supplementing with trace minerals. This result is consistent agreement with (Tovar et al. 2010). On the other hand, trace elements as well as $(\mathrm{Fe}, \mathrm{Zn}$ and $\mathrm{Cu})$ recorded the highest values with T3 ( 78.52, 27.38, 21.63 and 9.32 respectively )than other tested rations
The minerals may play an important role on milk production ,This is corresponding to ( Bawala et al., 2006) who reported that milk yield increased with increasing level of minerals as calcium, Phosphorus, Magnesium, Sodium and Potassium in diets .In addition to Iron , (78.52,27.38,21.63 and 9.32 respectively) than T1 ration ( $69.81,22.44,15.94$ and 8.87 respectively) and $\mathrm{T} 1$ ration $(60.05,27.38,21.63$ and 6.15 respectively). On the other side, Zinc and Cupper were significantly higher with $\mathrm{T} 3$ ration at same time manganese had lower value .

\section{Average feed intake}

The daily DM intake of dairy goats are presented in Table (3). The total DM intake as $\mathrm{g} / \mathrm{kg}$ $\mathrm{BW}$ or $\mathrm{g} / \mathrm{kg} \mathrm{w}^{0.75}$ were significantly $(\mathrm{p}<0.05)$ decreased with $\mathrm{T}_{2}$ ration (38.2 and 97.1) in compaction 
with $\mathrm{T}_{1}$ (39.9 and 101.5) and $\mathrm{T}_{3}$ (41.7 and 105.3 respectively). This increase in DMI with rations $\mathrm{T}_{1}$ and $\mathrm{T}_{3}$ was observed also by (Ibrahim et al. , 2012), using mixture of silages in dairy Zaraibi goats and Rahmany sheep.

Table 2. Mineral of experimental rations fed by dairy zaribi goats .

\begin{tabular}{|c|c|c|c|}
\hline \multirow[t]{2}{*}{ Items } & \multicolumn{3}{|c|}{ Experimental groups } \\
\hline & $T_{1}$ & $\mathbf{T}_{2}$ & $\mathbf{T}_{3}$ \\
\hline \multicolumn{4}{|c|}{ Minerals for experimental rations ( CFM + silages ) } \\
\hline Macro elements & & & \\
\hline Calcium, (Ca) & 0.46 & 0.84 & 0.67 \\
\hline Phosphorus, (P) & 0.41 & $0.71^{\mathrm{A}}$ & 0.55 \\
\hline Magnesium , (Mg) & 0.16 & 0.25 & 0.19 \\
\hline Sodium , $(\mathrm{Na})$ & 0.21 & 0.33 & 0.23 \\
\hline Potassium ,(K) & 1.34 & 1.47 & 1.18 \\
\hline \multicolumn{4}{|l|}{ Trace elements } \\
\hline Iron $(\mathrm{Fe})$ & $69.81^{\mathrm{A}}$ & 60.05 & 78.52 \\
\hline Zinc (Zn) & $22.44^{\mathrm{B}}$ & 23.97 & 27.38 \\
\hline Manganese (Mn) & $15.94^{\mathrm{B}}$ & 34.62 & 21.63 \\
\hline Cupper $(\mathrm{Cu})$ & $8.87^{\mathrm{A}}$ & 6.15 & 9.32 \\
\hline
\end{tabular}
significantly at $P<0.05$.

Table 3. Average feed intake feed efficiency of dairy Zaraibi goats fed the Experimental rations.

\begin{tabular}{|c|c|c|c|}
\hline \multirow[t]{2}{*}{ Items } & \multicolumn{3}{|c|}{ Experimental groups } \\
\hline & $\mathbf{T}_{1}$ & $\mathbf{T}_{2}$ & $\mathbf{T}_{\mathbf{3}}$ \\
\hline Duration of trial (day) & 120 & 120 & 120 \\
\hline Average body weight, $\mathrm{kg}$ & 41.80 & 41.58 & 40.91 \\
\hline Metabolic body size, $w^{0 . / 2}$ & 16.44 & 16.37 & 16.18 \\
\hline \multicolumn{4}{|c|}{ Dry matter intake (DMI g/h/d ) } \\
\hline Concentrate feed mixture(CFM) & 665 & 636 & 688 \\
\hline Silages & 1004 & 953 & 1015 \\
\hline DMI g / h /d & $1669^{\mathrm{A}}$ & $1589^{\mathrm{B}}$ & $1703^{\mathrm{A}}$ \\
\hline $3 \mathrm{~W}$ & 39.9 & 38.2 & 41.6 \\
\hline & 1.43 & 1.14 & 1.34 \\
\hline & $1.49^{\mathrm{A}}$ & $1.18^{\mathrm{B}}$ & $1.41^{\mathrm{A}}$ \\
\hline & 245 & 237 & 239 \\
\hline & $1.11^{\mathrm{A}}$ & $1.09^{\mathrm{B}}$ & $1.12^{\mathrm{A}}$ \\
\hline & 988 & 807 & 949 \\
\hline DC & $184.26^{\mathrm{A}}$ & $182.01^{\mathrm{A}}$ & $178.99^{\mathrm{B}}$ \\
\hline $\mathrm{CP} \mathrm{g} / \mathrm{kg}$ & 158 & 131 & 141 \\
\hline NFC g / day & 41.58 & 41.84 & 40.60 \\
\hline \multicolumn{4}{|l|}{ Daily water consumption } \\
\hline & $4.06^{\mathrm{A}}$ & $3.41^{\mathrm{B}}$ & $3.78^{\mathrm{A}}$ \\
\hline & 97.13 & 82.00 & 92.40 \\
\hline & 247.0 & 208.0 & 233.6 \\
\hline $\mathrm{Ml} / \mathrm{g} \mathrm{DM}$ intake & 2.43 & 2.15 & 2.22 \\
\hline \multicolumn{4}{|l|}{ Feed efficiency } \\
\hline $\mathrm{NE}(\mathrm{MJ} / \mathrm{kg}) * *$ & 0.359 & 0.373 & 0.356 \\
\hline NED $($ Mcal $/ \mathrm{kg}) * * *$ & 1.50 & 1.56 & 1.49 \\
\hline NEL (M cal / kg) **** & 0.659 & 0.756 & 0.736 \\
\hline NEL / NED $(\%)$ & $43.93^{\mathrm{A}}$ & $48.46^{\mathrm{b}}$ & $49.40^{\mathrm{B}}$ \\
\hline
\end{tabular}

$A$ and $B$ Means in the same row with different superscripts differ significantly at $\mathrm{P}<0.05$.

* DDM :Digestion dry matter \% of DM = 88.9- 0.779 X( ADF \% OF DM ) Schroeder, 1996 )

** NE : Net energy $(M J / k g)=$ TDN \% X 0.0245 $)-0.12 / 4.184$ ( NRC, 2001)

***NED $($ Mcal $/ \mathrm{kg})=($ TDN\% $) X(0.0245)-0.12($ NRC 2001 $)$

$* * * * \operatorname{NEL}(\mathrm{Mcal} / \mathrm{kg})=(0.0929 \mathrm{X}$ fat $\%)+(0.0547 \mathrm{x}$ protein $\%)+$ ( $0.0395 \times$ lactose \%).( NRC. 2001).

In addition, water consumption recorded the lowest values with $\mathrm{T} 2$ ration $(3.41 \mathrm{~L} / \mathrm{h} / \mathrm{d})$ whereas the higher value with $\mathrm{T} 1$ ration $(4.06 \mathrm{~L} / \mathrm{h} / \mathrm{d})$ and $\mathrm{T} 3$ ration had moderate value. Generally, the quantity of daily water consumption in present study is nearly similar to those obtained by (Soliman et al. ,2010) on growing Zaraibi goats .In addition to, the feed efficiency as well as (NE,NED and NEL) were higher with $\mathrm{T}_{2}$ ration $\left(0.373,1.56\right.$ and 0.756 respectively) in comparison of $\mathrm{T}_{1}$ $\left(0.359,1.50\right.$ and 0.669 respectively) and $\mathrm{T}_{3}$ ration $(0.356$ , 1.49 and 0.736 respectively). While (NEL / NED \%) was higher with $\mathrm{T}_{3}(49.40 \%)$ than those of $\mathrm{T}_{2}(48.46 \%)$ and $\mathrm{T}_{3}(43.93 \%)$.

Digestion coefficients and nutritive values

Results in Table (4) showed that $T_{2}$ was significantly $(p<0.05)$ highest digestibility coefficients of $\mathrm{CP}, \mathrm{CF}, \mathrm{EE}, \mathrm{NFE}$ and $\mathrm{GE}(76.94,64.91,74.82$, 74.13 and $66.25 \%$ respectively) while DM had lower value ( 69.39) than of those $\mathrm{T}_{1}(71.37,75.28,63.17$, $72.56,71.61$ and 63.31 respectively ) and $\mathrm{T}_{3}$ $(74.32,74.91,61.88,72.94,72.24$ and $64.17 \%$ respectively).

Table 4. igestion coefficients and nutritive values of experimental fed by zaribi goats .

\begin{tabular}{|c|c|c|c|}
\hline \multirow[t]{2}{*}{ Items } & \multicolumn{3}{|c|}{ Experimental groups } \\
\hline & $T_{1}$ & $\mathbf{T}_{2}$ & $\mathbf{T}_{3}$ \\
\hline \multicolumn{4}{|c|}{ Nutritive digestibility, \% } \\
\hline DM & 68.97 & 69.37 & 70.62 \\
\hline $\mathrm{OM}$ & $71.37^{\mathrm{B}}$ & $73.69^{\mathrm{A}}$ & $74.32^{\mathrm{A}}$ \\
\hline $\mathrm{CP}$ & $75.28^{\mathrm{B}}$ & $76.94^{\mathrm{A}}$ & $74.91^{\mathrm{B}}$ \\
\hline $\mathrm{CF}$ & $63.17^{\mathrm{A}}$ & $64.91^{\mathrm{A}}$ & $61.88^{\mathrm{B}}$ \\
\hline $\mathrm{EE}$ & $72.56^{\mathrm{B}}$ & $74.82^{\mathrm{A}}$ & $72.94^{\mathrm{B}}$ \\
\hline NFE & $71.61^{\mathrm{A}}$ & $74.13^{\mathrm{A}}$ & $72.24^{\mathrm{B}}$ \\
\hline GE & $63.31^{\mathrm{B}}$ & $66.25^{\mathrm{A}}$ & $64.17^{\mathrm{B}}$ \\
\hline TDN \% & $66.34^{\mathrm{A}}$ & $68.61^{\mathrm{A}}$ & $65.68^{\mathrm{B}}$ \\
\hline TDN g / kg milk & 949 & 807 & 988 \\
\hline $\mathrm{DCP} \%$ & $11.04^{\mathrm{A}}$ & $11.46^{\mathrm{A}}$ & $10.51^{\mathrm{B}}$ \\
\hline \multirow[t]{2}{*}{ DCP g / kg milk } & 141 & 131 & 158 \\
\hline & \multicolumn{3}{|c|}{ Fiber fractions, $\%$} \\
\hline NDF & $68.40^{\mathrm{A}}$ & $61.90^{\mathrm{B}}$ & $66 . .28^{\mathrm{A}}$ \\
\hline $\mathrm{ADF}$ & 64.30 & 63.80 & 63.93 \\
\hline ADL & $35.90^{\mathrm{A}}$ & $32.69^{\mathrm{B}}$ & $34.81^{\mathrm{A}}$ \\
\hline Hemicelluloses & $64.80^{\mathrm{A}}$ & $64.02^{\mathrm{A}}$ & $60.13^{\mathrm{B}}$ \\
\hline \multirow[t]{2}{*}{ Celluloses } & $70.90^{\mathrm{A}}$ & $65.32^{\mathrm{B}}$ & $64.77^{\mathrm{B}}$ \\
\hline & \multicolumn{3}{|c|}{ Metabolizability \% } \\
\hline ME( kcal. / kg) & $36.27^{\mathrm{B}}$ & $38.15^{\mathrm{A}}$ & $37.78^{\mathrm{A}}$ \\
\hline $\mathrm{ME} / \mathrm{GE}$ & 59.67 & 57.58 & 56.52 \\
\hline
\end{tabular}

$A$ and $B$ Means in the same row with different superscripts differ significantly at $P<\mathbf{0 . 0 5}$.

Moreover, the feed conversion as TDN and DCP for milk yield were significantly $(\mathrm{p}<0.05)$ higher with milk yield of $\mathrm{T}_{3}$ ration (988 and 158 respectively) followed by T2 ( 949 and 141 respectively ) and, while the lowest values were showed with T2 ( 807 and 131 respectively ) and fat corrected milk at same trend. At the same time, the ratio of roughage to concentrate were similar for all treatments (60:40). Generally, the increased silage intake gave positive evidence that silage was good quality as reported by Ahmed et al. (2001) with lactating goats . DMI for kg milk and FCM had recorded reflected values of DMI \% of BW and $\mathrm{W}^{0.75}$ for all experimental treatments. Subsequent, improvement in digestion coefficients could be due to the high energy value of maize silage. In this respect, ( Zeid and Shakweer ,2011) reported that high inclusion of maize silage in ration improved digestibility coefficients .However, the results of fiber fractions as well as( NDF, ADF, ADL, hemicelluloses 
and celluloses \%) showed that $\mathrm{T} 1$ ration had the highest values $(68.40,64.30,35.90,64.80$ and 70.90 respectively ) whereas, the lowest values were detected with $\mathrm{T} 2$ ration except of cellulose and hemicellulose digestibility were higher. On the other hand metabolisable energy (kcal / kg)was higher with T2 ration (38.15) followed by $\mathrm{T} 3(37.78)$ and the lowest value had detected with T1(36.27). In addition ME/ GE was recorded the highest value with $\mathrm{T} 1$ (59.67) and T3 ration had lowest value( 56.52) .T2 ration was moderately (57.58).

\section{Nitrogen utilization and minerals utilization}

Data in Table (5) showed that nitrogen intake(NI), feces nitrogen (FN), urine nitrogen (UN) and nitrogen excretion (NE) of $\mathrm{T} 1$ ration were higher values( $39.18,12.04,15.48$ and $27.42 \mathrm{~g} / \mathrm{h} / \mathrm{d}$ respectively) followed by $\mathrm{T} 3$ ration $(38.23,11.76,13.58$ and 25.34 respectively ) while T2 was moderate valued ( $37.86,11.49,14.81$ and $26.30 \mathrm{~g} / \mathrm{h} / \mathrm{d}$ respectively) and T3 ( $38.23,11.76,13.58$ and $25.34 \mathrm{~g} / \mathrm{h} / \mathrm{d}$ respectively). Moreover, nitrogen balance (NB) and (NB/NI\%) had recorded the highest values with $\mathrm{T} 1$ (11.66 and 29.76 respectively) than those of $\mathrm{T} 2$ ration $(11.56,30.53$ respectively) and $\mathrm{T} 3$ ( 12.89 and $33.72 \mathrm{~g} \mathrm{/} \mathrm{h/d}$ respectively).This may be a related to the higher $\mathrm{CP}$ digestibility in ration $\mathrm{T} 1$ and $\mathrm{T} 2$ thanT3 ration. Nitrogen balance obtained in this study were closed to that reported by (Yacout and El- Badawi , 2001) and (Mohsen et al.,2006) who found that $\mathrm{N}$ balance of goats fed rations contained $12 \% \mathrm{CP}$ was $41.4 \mathrm{~g} / \mathrm{h} / \mathrm{d}$ ).

Table 5. Nitrogen retention of tested rations fed by dairy zaribi goats .

\begin{tabular}{lccc}
\hline Items & \multicolumn{3}{c}{ Experimental groups } \\
& $\mathbf{T}_{\mathbf{1}}$ & $\mathbf{T}_{\mathbf{2}}$ & $\mathbf{T}_{\mathbf{3}}$ \\
\hline Nitrogen balance \% & & & \\
Nitrogen intake(NI)g/h/d & $39.18^{\mathrm{A}}$ & $37.86^{\mathrm{B}}$ & $38.23^{\mathrm{A}}$ \\
Fecal nitrogen(FN)g /h/ d & $12.04^{\mathrm{A}}$ & $11.49^{\mathrm{B}}$ & $11.76^{\mathrm{B}}$ \\
Urinary nitrogen( UN ) g / h / d & $15.48^{\mathrm{A}}$ & $14.81^{\mathrm{A}}$ & $13.58^{\mathrm{B}}$ \\
Nitrogen excretion (FU + UN ) & $27.42^{\mathrm{A}}$ & $26.30^{\mathrm{A}}$ & $25.34^{\mathrm{B}}$ \\
Nitrogen balance (NB) g / h / d) & $11.66^{\mathrm{B}}$ & $11.56^{\mathrm{B}}$ & $12.89^{\mathrm{A}}$ \\
NB / NI , \% & $29.76^{\mathrm{B}}$ & $30.53^{\mathrm{B}}$ & $33.72^{\mathrm{A}}$ \\
\hline
\end{tabular}

$A$ and $B$ Means in the same row with different superscripts differ significantly at $P<0.05$.

\section{Average daily milk yield}

New-born kids were kept with mothers till weaning, except during time of milk yield recording. During suckling period, milk yield was recorded by weekly for all does while separating kids from mothers. Results in Table (6) revealed that actual milk yield (AMY) and 4\% FCM yield of dairy zaribi goats fed tested rations T2 were the highest being (1.390 and $1.350 \mathrm{~kg} / \mathrm{d}$ ) than those fed T3 (1.274 and1.206) ,T1 (1.168 and 1.119) respectively. The higher milk yield recorded by goats fed $\mathrm{T} 2$ ration .This results indicated that using hybrid of El-Ryanah x El-Shamia maize and berseem silage as source of roughage made of the increasing milk yield and agreed with those obtained by (Mahmoud et al .,1992) who reported that milk yield of lactation animals increased with corn silage in the ration.
As milk composition of goats as affected by feeding rations containing hybrid El-Ryanah x ElShamia maize silage and berseem silage and obtained data illustrated that there significant differences ( $p$ $<0.05$ ) in milk composition among the different groups .The percentage of fat, total solid, total nitrogen, lactose and net energy of $\mathrm{T} 2$ ration were significantly $(\mathrm{p}<0.05)$ higher $(3.81,13.40,7.30,5.31$ and 1.60 respectively), while percentage of protein , solid nonfat and Ash had detected lower values(3.38, 9.59 and 0.88 ) than those of $\mathrm{T} 1$ and $\mathrm{T} 3$ rations, these results may be due to the higher fermentation of fibers into volatile fatty acid (17.91, 20.55 and 18,62 ) for $\mathrm{T} 1, \mathrm{~T} 2$ and $\mathrm{T} 3$ respectively these results agreement with those obtained by (Ahmed et al., 2013 ).The present results were related to rumen fermentation, blood metabolism and microorganisms convert much of the dietary carbohydrate to VFAs which are absorbed into the blood steam and became the primary source of energy for the goats .The VFAs also serve as important building blocks for milk fat as well as lactose .On the other hand, (Vatandoost et al.,2011) found that lactating dairy goats increased in milk production when using hybrid maize which affect through changes in feed intake .

Table 6. Effect of feeding experimental rations on milk production,milk constituents of dairy zaribi goats .

\begin{tabular}{lccc}
\hline \multicolumn{1}{c}{ Items } & \multicolumn{3}{c}{ Experimental groups } \\
& $\mathbf{T}_{\mathbf{1}}$ & $\mathbf{T}_{\mathbf{2}}$ & $\mathbf{T}_{\mathbf{3}}$ \\
Total Milk yield & $\mathbf{1 4 0 . 1 6}^{\mathbf{B}}$ & $\mathbf{1 6 6 . 8 0}^{\mathrm{A}}$ & $\mathbf{1 4 9 . 6 4 ^ { \mathrm { A } }}$ \\
\hline (kg / h / period ) & $1.168^{\mathrm{B}}$ & $1.390^{\mathrm{A}}$ & $1.274^{\mathrm{A}}$ \\
\hline Daily Milk yield(kg/h/ d ) & $1.119^{\mathrm{B}}$ & $1.350^{\mathrm{A}}$ & $1.205^{\mathrm{B}}$ \\
FCM ( kg / h / d ) & 3.72 & 3.81 & 3.64 \\
Fat \% & 41.62 & 51.44 & 43.86 \\
Fat Yield (g / h / d ) & 3.65 & 3.38 & 3.47 \\
Protein \% & $40.84^{\mathrm{B}}$ & $45.63^{\mathrm{A}}$ & $41.85^{\mathrm{B}}$ \\
Protein Yield (g / h / d ) & $1: 1.05$ & $1: 1.13$ & $1: 1.05$ \\
Protein : Fat ( kg / h / d ) & 13.38 & 13.40 & 13.14 \\
Total solid \% & $6.53^{\mathrm{B}}$ & $7.30^{\mathrm{A}}$ & $6.70^{\mathrm{B}}$ \\
Total Nitrogen (TN) & 9.66 & 9.59 & 9.50 \\
Solid Non Fat ( SNF ) & $4.89^{\mathrm{B}}$ & $5.31^{\mathrm{A}}$ & $5.27^{\mathrm{A}}$ \\
Lactose \% & 0.91 & 0.88 & 0.76 \\
Ash \% & 1.54 & 1.60 & 1.52 \\
Net Energy(Mcal/Kg milk ) &
\end{tabular}

$A$ and $B$ Means in the same row with different superscripts differ significantly at $P<0.05$.

\section{Rumen microorganisms}

Results in Table (7) showed that $\mathrm{pH}$ values $\mathrm{T} 3$ ration at 3 and $6 \mathrm{hr}$. were significantly $(\mathrm{p}<0.05)$ higher (6.24and 6.35 respectively) than those of $\mathrm{T} 1$ ration (6.22and 6.33 respectively) and higher values recorded with T2 ration(6.19 and 6.31 respectively). Meanwhile , TVFAS of T1 ration was significantly $(\mathrm{p}<0.05)$ lower at 0,3 and $6 \mathrm{hr}$. (21.45, 23.91 and 20.47 respectively) than $\mathrm{T} 3$ ration $(23.18,24.62$ and 21.89 respectively) but the highest values were recorded with $\mathrm{T} 2$ ration $(24.72$, 26.55 and 23.18 respectively)

On the other hand $\mathrm{NH} 3-\mathrm{N}$ of $\mathrm{T} 3$ ration was significantly $(\mathrm{p}<0.05)$ lower at 0,3 and $6 \mathrm{hr}$. (21.83, 27.14 and 24.78 respectively) than $\mathrm{T} 1$ ration $(24.38$, 28.47 and 26.89 respectively), on the other side the 
highest values were recorded with $\mathrm{T} 2$ ration (27.15, 31.29 and 29.61 respectively ). As rumen microbial count and classification as well as(Total bacterial count , Cellulolytic bacterial and Cellulolytic bacterial) . As Total bacterial count showed $\mathrm{T} 2$ ration recorded the highest values $(42.45,43.547$ and 44.39) at 0,3 and 6 hr. respectively post feeding followed by T1 ( 40.69 , 36.18 and 38 77) whereas $\mathrm{T} 3$ ration had detected the lowest values ( $38.45,35.76$ and 33.27) at 0,3 and 6 hr. respectively. The results are in harmony with those of (Kurihara et al.,1998) they observed that the peak of bacterial counts was between 3 and 6 hrs after feeding. Moreover, Cellulolytic bacterial of $\mathrm{T} 1$ ration was significantly $(\mathrm{p}<0.05)$ hugher $(3.84,4.16$ and 3.96$)$ at 0,3 and $6 \mathrm{hr}$. respectively, and the lowest values detected with $\mathrm{T} 3$ ration $(3.37,3.64$ and 3.24) at 0,3 and $6 \mathrm{hr}$. respectively, but T2 ration was moderate values .On the other side, Protozoa was higher with T3 ration ( 4.06, 4.27 and 4.38) than those of $\mathrm{T} 1$ ration, but T2 ration had the lowest values .These results agreement with (Khampa and Wanapat ,2007) and (Behraka et al.,1991) reported that rumen have a large and more active bacterial population, it may help to increase the rate of digestion. In the other studies, (Nour et al., 1989) found that feeding animals on concentrate with high roughages increased the total protozoa count in the rumen. Also the results were in Harmony with those obtained

Table 7. Effect of experimental rations fed by lactating Zaribi goats on rumen microorganisms.

\begin{tabular}{|c|c|c|c|c|}
\hline \multirow[b]{2}{*}{ Items } & \multirow{2}{*}{ Time } & \multicolumn{3}{|c|}{ Experimental groups } \\
\hline & & $\mathbf{T}_{1}$ & $\mathbf{T}_{2}$ & $\mathbf{T}_{3}$ \\
\hline \multirow[t]{3}{*}{$\mathrm{pH}$ value } & 0 & 6.44 & 6.37 & 6.43 \\
\hline & 3 & $6.22^{\mathrm{B}}$ & $6.19^{\mathrm{B}}$ & $6.24^{\mathrm{A}}$ \\
\hline & 6 & $6.33^{\mathbf{B}}$ & $6.31^{\mathbf{B}}$ & $6.35^{\mathrm{A}}$ \\
\hline \multirow[t]{3}{*}{ TVFAS ( MEQ/ 100 ml) } & 0 & $21.45^{\mathrm{B}}$ & $24.72^{\mathrm{A}}$ & $23.18^{\mathbf{A}}$ \\
\hline & 3 & $23.91^{\mathbf{B}}$ & $26.55^{\mathrm{A}}$ & $24.62^{\mathbf{B}}$ \\
\hline & 6 & $20.47^{\mathbf{B}}$ & $23.18^{\mathrm{A}}$ & $2189^{\mathbf{B}}$ \\
\hline \multirow[t]{3}{*}{ NH3-N( mg / 100 ml ) } & 0 & $24.38^{\text {B }}$ & $27.15^{\mathbf{A}}$ & $21.83^{\mathbf{B}}$ \\
\hline & 3 & $28.47^{\mathbf{B}}$ & $31.29^{\mathrm{A}}$ & $27.14^{\text {B }}$ \\
\hline & 6 & $26.89^{\mathbf{B}}$ & $29.61^{\mathbf{A}}$ & $24.78^{\text {B }}$ \\
\hline Total bacterial count $(10 / \mathrm{ml})$ & 0 & $34.69^{\mathrm{B}}$ & $42.17^{\mathbf{A}}$ & $38.45^{\mathbf{A}}$ \\
\hline \multirow[t]{2}{*}{ after 3 hrs. } & 3 & $3818^{\mathrm{B}}$ & $43.46^{\mathrm{A}}$ & $35.76^{\mathrm{C}}$ \\
\hline & 6 & $36.77^{\mathbf{B}}$ & $44.39^{\mathbf{A}}$ & $33.27^{\mathbf{B}}$ \\
\hline \multirow[t]{3}{*}{ Cellulolytic bacterial $\left(10^{4} / \mathrm{ml}\right)$ af } & 0 & 3.84 & 3.45 & 3.37 \\
\hline & 3 & $4.15^{\mathrm{A}}$ & $3.72^{\text {B }}$ & $3.64^{\text {B }}$ \\
\hline & 6 & $3.96^{\mathrm{A}}$ & $3.66^{\mathrm{A}}$ & $3.24^{\mathrm{B}}$ \\
\hline \multirow{3}{*}{$\begin{array}{l}\text { Total protozoa count }\left(10^{4} / \mathrm{m}\right. \\
\text { after } 3 \mathrm{hrs} \text {. }\end{array}$} & 0 & $3.47^{\mathrm{A}}$ & $2.88^{\mathbf{B}}$ & $4.06^{\mathbf{A}}$ \\
\hline & 3 & $2.97^{\text {B }}$ & $3.11^{\mathrm{B}}$ & $4.27^{\mathrm{A}}$ \\
\hline & 6 & $2.91^{\text {B }}$ & $3.24^{\mathrm{B}}$ & $4.38^{\mathbf{B A}}$ \\
\hline
\end{tabular}

$\mathrm{A}, \mathrm{B}$ and $\mathrm{C}$ Means in the same row with different superscripts differ significantly at $P<0.05$.

\section{Blood profile}

Data in Table (8) explain that T3 had significantly decrease of RBC and hemoglobin (11.31 and 9.22) than $\mathrm{T} 1$ (11.92 and 9.67) and $\mathrm{T} 3$ rations ( 12.24 and 10.45), At same time, MCV , MCH MCHC were higher with $\mathrm{T} 1$ comparison of $\mathrm{T} 2$ and $\mathrm{T} 3$ rations. HCT \% was recorded the the higher value with T3( 28.73) and the lower value had detected with T2 (16.14\%) Meanwhile, the quantitative and qualitative parameters of milk production of dairy goats depend on nutritional supply and blood constituents. ( Cupta et al. ,2007) found that cells of lactating mammary glands utilize as much as $80 \%$ of available nutrients for synthesis of milk from blood .In addition to serum biochemical data are presented in Table (7). Showed that total protein, albumen, globulin, glucose ,Urea-N and Cholesterol of T2 ration had increased 7.52, .81,4. $1,72.45$ and 62.18 respectively) but creatinine, AST and ALT concentrations were decreased $(0.49,13.87$ and123.17 respectively) than other tested rations. The obtained values are within normal range reported by (Jain,1986) for hematological parameters and (Kaneko, 1986)

Table 8. Effect of feeding experimental rations e on hematology parameters .

\begin{tabular}{lccc}
\hline \multirow{2}{*}{ Items } & \multicolumn{3}{c}{ Experimental groups } \\
& $\mathbf{T}_{\mathbf{1}}$ & $\mathbf{T}_{\mathbf{2}}$ & $\mathbf{T}_{\mathbf{3}}$ \\
\hline RBC x ${ }^{10} / \mu \mathrm{L}$ & $11.92^{\mathrm{A}}$ & $12.24^{\mathrm{A}}$ & $11.31^{\mathrm{B}}$ \\
$\mathrm{HB} \mathrm{g/Dl}$ & $9.67^{\mathrm{B}}$ & $10.45^{\mathrm{A}}$ & $9.22^{\mathrm{B}}$ \\
$\mathrm{HCT} \%$ & $24.18^{\mathrm{A}}$ & $16.14^{\mathrm{B}}$ & $28.73^{\mathrm{A}}$ \\
$\mathrm{MCV}, \mathrm{FL}$ & $32.81^{\mathrm{A}}$ & $32.61^{\mathrm{A}}$ & $24.66^{\mathrm{B}}$ \\
$\mathrm{MCH}, \mathrm{Pg}$ & $11.54^{\mathrm{A}}$ & $10.67^{\mathrm{A}}$ & $8.02^{\mathrm{B}}$ \\
MCHC \% & $33.49^{\mathrm{A}}$ & $30.11^{\mathrm{A}}$ & $26.55^{\mathrm{B}}$ \\
Serum Biochemical & & & \\
Total protein g /dL & $7.23^{\mathrm{B}}$ & $7.52^{\mathrm{A}}$ & $7.16^{\mathrm{B}}$ \\
Albumin g//dL & 2.71 & 2.81 & 2.78 \\
Globulin & $4.52^{\mathrm{B}}$ & $4.71^{\mathrm{A}}$ & $4.38^{\mathrm{B}}$ \\
Creatinine & $0.68^{\mathrm{A}}$ & $0.49^{\mathrm{B}}$ & $0.74^{\mathrm{A}}$ \\
Glucose mg/dl & $66,48^{\mathrm{B}}$ & $72.45^{\mathrm{A}}$ & $64.24^{\mathrm{B}}$ \\
Urea-N mg/ dL & $55.20^{\mathrm{A}}$ & $62.18^{\mathrm{A}}$ & $49.91^{\mathrm{B}}$ \\
AST $\mu / \mathrm{L}$ & $18.11^{\mathrm{A}}$ & $13.87^{\mathrm{B}}$ & $16.53^{\mathrm{A}}$ \\
ALT $\mu / \mathrm{L}$ & $142.09^{\mathrm{A}}$ & $123.17^{\mathrm{B}}$ & $136.23^{\mathrm{A}}$ \\
ALT / AST & $9.44^{\mathrm{A}}$ & $8.59^{\mathrm{A}}$ & 8.85 \\
Cholesterol, mg/dl & $113.35^{\mathrm{A}}$ & $115.11^{\mathrm{A}}$ & $104.36^{\mathrm{B}}$ \\
\hline A & & & \\
\hline
\end{tabular}

$A$ and $B$ Means having different superscripts within the same row are significantly different at $(\mathbf{P}<0.05)$.

\section{Feed utilization}

Data of average feed intake and milk yield during experimental period as well as feed conversion efficiency of the dairy Zaraibi goats are summarized in Table (9).The data indicated that the average milk yield recorded significantly the highest value with $\mathrm{T}_{2}$ ration $(1.390 \mathrm{~kg} / \mathrm{h} / \mathrm{d})$ followed by $\mathrm{T}_{3}$ ration $(1.274 \mathrm{~kg} / \mathrm{h} / \mathrm{d})$ and lastly, $\mathrm{T}_{1}$ ration had detected the lowest value $(1.168 \mathrm{~kg} / \mathrm{h} / \mathrm{d})$. Thus , the feed conversion calculated as $\mathrm{DM}$ and CP (intake / milk yield) was better with $\mathrm{T}_{2}$ ration (1.14 and 236.60) and $T_{1}$ ration(1.43 and 244.70) compared with $\mathrm{T}_{3}$ ration (1.34 and 238.93) respectively. Similar results were observed by ( Ahmed et al.,2013) using mixture of silages for dairy Zaraibi goats. In recent study, Ibrahim et al. (2012) observed that feed conversion efficiency based on DM and TDN was better with Rahmany sheep fed mixed silage (legume $\mathrm{x}$ grass silage ) than those fed cowpea or millet $x$ napier grass hybrid alone. Generally, the obtained values of feed conversion are within the normal range given by( Ibrahim et al., 2008) . 
Table 9. Feed conversion of lactating Zaraibi does fed experimental rations.

\begin{tabular}{lccc}
\hline Item & \multicolumn{3}{c}{ Groups } \\
& $\mathbf{T}_{\mathbf{1}}$ & $\mathbf{T}_{\mathbf{2}}$ & $\mathbf{T}_{\mathbf{3}}$ \\
\hline No . of Zaraibi goats & 8 & 8 & 8 \\
Average body weight, kg & 41.80 & 41.58 & 40.91 \\
Metabolic body size, w 0.75 & 16.44 & 16.37 & 16.18 \\
Total DM intake, g/h/d & $1669^{\mathrm{A}}$ & $1589^{\mathrm{B}}$ & $1703^{\mathrm{A}}$ \\
CP intake, g / h /d & 244.70 & $236 . .60$ & 238.93 \\
Daily Milk yield ( kg / h / d ) & $1.168^{\mathrm{B}}$ & $1.390^{\mathrm{A}}$ & $1.274^{\mathrm{A}}$ \\
FCM ( kg / h / d ) & $1.119^{\mathrm{B}}$ & $1.350^{\mathrm{A}}$ & $1.206^{\mathrm{B}}$ \\
Feed conversion : & & & \\
Kg DM / kg milk & 1.43 & 1.14 & 1.34 \\
Kg DM / kg fat correction milk & 1.49 & 1.24 & 1.41 \\
(FCM) & 950 & 784 & 879 \\
g TDN / kg milk & 210 & 170 & 188 \\
g TDN / kg fat correction milk (FCM) & $990^{\mathrm{A}}$ & $807^{\mathrm{B}}$ & $929^{\mathrm{A}}$ \\
g CP / kg milk & 219 & 175 & 140 \\
g CP / kg FCM & 219 &
\end{tabular}

$A$ and $B$ Means having different superscripts within the same row are significantly different at $(\mathbf{P}<0.05)$.

\section{Economic efficiency}

Data of economic milk efficiency Table (10) showed that differences among treatment rations. Dairy zaribi goats fed $\mathrm{T} 3$ ration showed the highest average daily feed cost $(2.27 \mathrm{LE})$ and the lowest with T2 $(2.08$ LE ), whereas T1 had moderately ( $2.24 \mathrm{LE}$ ). Meanwhile, price of milk yield of T1 ration was the lowest ( $4.67 \mathrm{LE})$ and $\mathrm{T} 2$ ration the highest value $(5.56$ LE ).These results may be due saving higher amount of high expensive feed concentrate mixture(CFM) and also replacing low expensive silage was increasing milk yield with feeding ration containing $100 \%$ hybrid Ryanah x Shamia maize silage(T2).

Table 10. Economical efficiency (LE) of tested rations on productivity of dairy zaribi goats .

\begin{tabular}{|c|c|c|c|}
\hline \multirow{2}{*}{$\begin{array}{l}\text { Items } \\
\text { Feed efficiency : }\end{array}$} & \multicolumn{3}{|c|}{ Experimental groups } \\
\hline & $* \mathbf{T}_{1}$ & $* * \mathbf{T}_{2}$ & $* * * \mathbf{T}_{3}$ \\
\hline \multicolumn{4}{|l|}{ Av. feed intake $\mathrm{g} / \mathrm{h} / \mathrm{d}$} \\
\hline $\mathrm{CFM}$ intake, $\mathrm{g} / \mathrm{h} / \mathrm{d}$ & 665 & 636 & 688 \\
\hline Silage intake, $\mathrm{g} / \mathrm{h} / \mathrm{d}$ & 1004 & 953 & 1015 \\
\hline Total DM intake , $\mathrm{g} / \mathrm{h} / \mathrm{d}$ & $1669^{\mathrm{A}}$ & $1589^{\mathrm{B}}$ & $1703^{\mathrm{A}}$ \\
\hline $\begin{array}{l}\text { Cost of total daily feed } \\
\text { intake (LE) }\end{array}$ & 2.24 & 2.08 & 2.27 \\
\hline $\begin{array}{l}\text { Average milk production } \\
(\mathrm{kg} / \mathrm{h} / \mathrm{d})\end{array}$ & $1.168^{\mathrm{B}}$ & $1.390^{\mathrm{A}}$ & $1.274^{\mathrm{A}}$ \\
\hline Price of milk (LE) & $4.67^{\mathrm{B}}$ & $5.56^{\mathrm{A}}$ & $5.10^{\mathrm{B}}$ \\
\hline Return , LE & $2.43^{\mathrm{B}}$ & $3.48^{\mathrm{A}}$ & $2.83^{\mathrm{B}}$ \\
\hline Net revenue $\%$ & $52.03^{B}$ & $62.59^{\mathrm{A}}$ & $55.49^{\mathrm{B}}$ \\
\hline Economic efficiency (\%) & - & $12.03^{\mathbf{A}}$ & $6.65^{\mathrm{B}}$ \\
\hline
\end{tabular}

$A$ and $B$ Means having different superscripts within the same row are significantly different at $(\mathrm{P}<0.05)$.

These results are in accordance with those obtained by ( Saleh et al. ,2007) who found that goats feed maize silage along with concentrate was the most economic milk production . Feeding of lactating goats on ration containing corn silage reduced daily feed cost and improved milk yield, milk composition and feed conversion (Mahmoud et al.,1992).Also economic efficiency expressed as the ratio between the price of daily milk and daily feed cost ,the results indicated that the highest economic efficiency for goats fed $\mathrm{T} 2$ ration (12.03), while the lowest economic was in T1 ration .

- Market price of CFM $=3000 \mathrm{LE} /$ ton , $\mathrm{kg}$ milk $=4$ LE. - Price of HSRS $=180 \mathrm{LE} /$ ton ,

- Price of Egyptian berseem silage $=240 \mathrm{LE} /$ ton Price of Egyptian berseem silage $\mathrm{x}$ HSRS $=210 \mathrm{LE} /$ ton - Net revenue $=\{($ Selling income of milk - coast of feed intake (LE) $\} 100 \mathrm{LE}$ for rice straw

* Egyptian berseem silage (100\%) ** Hybrid Shamia x raianah maize silage ( HSRS 100\%) silage . *** Hybrid Shamia x raianah maize ( HSRS)+Egyptian berseem silage $(1: 1)$.

\section{CONCLUSION}

In conclusion, replacement berseem as $(100 \%$ or 50\%)by hybrid El-Ryanah x El-Shamia maize created changes of small magnitude in the concentrations of milk fat and milk protein in the present work. According to the literature, maize silage often had similar effects on yield and composition of milk, in spite of the large differences in their carbohydrate fraction. These effects include a lesser quantity but more concentrated milk when hybrid El- Ryanah x El--Shamia maize is replaced, but a constant milk yield and higher concentrations of fat and protein .

\section{REFFERNCES}

Adogla - Bessa ,T. and Aganga, A.A. (2000).Milk production of Tswana goats fed diets containing different levels of energy. South African Journal of South African Journal of Animal .Science. 30 (1): 77-81.

Ahmed, M. E., A.M. Abdelhamid, F.F. Abou Ammou, E.S. Soliman,N.M.El-Kholy and E.1. Shehata (2001). Response of milk production of Zaraibi goats to feeding silage containing different levels of teosinte and kochia.Egyptian J.Nutrition and Feeds, 4: 141

Ahmed M.E., E.I. Shehata, M. E. El-Kholany, G.I. ElEmam, E.I. Khalifa and H. Bahery (2013). Productive performance of Zaraibi goats fed berseem and/or Triticale silage. The $4^{\text {th }}$ Scientific Conference of Animal Production Research Institute, 184:192.

Al-Yousef,Y.M.; F.N.Al-Mulhim;G.A.El-Hag and G.A.Al-Gsim ,(1994).utilization of diets with different forage mixtures with Egyptian berseem by growing awassi lambs. Annals. Agric.,Sci.AIN Shams Univ.,39(2),663-670.

A.O.A.C.( 2000 ) . Association of Official Analytical Chemists Official Methods of Analysis $6 \mathrm{ed}$. Washington D.C.

A.O.A.C.( 2005) .Association of Official Analytical Chemists Official Methods of Analysis 7 ed. Washington D.C.

Bawala,T.O., Isah, O. A. and Akinsoyina, A. O. (2006). Studies on milk mineral composition of lactaing West African Dwarf Goats. J. Anim. Vet. Adv.,5 (10): 805-809.

Beharka A.A., Nagaraja T.G., Morrill J.L.,Kennedy G.A.,Klemm R.D.,(1991).Effects of form of the diet on anatomical, microbial, and fermentative development of the rumen of neonatal. calves. J. Dairy Sci. 81, 1946-1955 . 
Blaxter. K.L, 1966). The Energy Metabolism of Ruminants. The 2 nd. Charles Thomes Publisher. Spring Field. Illinois, USA.

Bradley,R.L., Arnold, E.,Barbano, D.M.,Semerad, R.G.,Smith, D.E.and Vines, B.K. (1992). Chemical and physical methods. In: Marshall, R.T. (Ed.),Standard Methods for the Examination of Dairy Products. American Public Health Association, Washington, D C.USA. pp:433-531

Calsamiglia , S.;StemM.D. andFirnkine J.L. ( 1995 ) . Effect of protein source on nitrogen metabolism in continuous culture and intestinal digestion in vitro .J. Anim. Sci.73: 1819.

Drupt ., E( 1974). Colorimetric determination of albumen .Biol. J.9.777. Duncan,D.B.(1955). Multiple range and multiple F-test Biometrics, 11: 1- 42 .

Eadie, J.M.P.;Hobson ,N. and Man, S.O.(1967). A note on some comparisons between the content of barely fed steers and that of young calves fed on high concentration ration .J.Anim. Prod. ,9: 247.

El-Sayes, M.F., M.R.M. Mostafa and M.K. Hathout (1997). Nutritional and economic efficiency for using the maize silage in fattening calves locally. $5^{\text {th }}$ World Buffalo Congress. nimal Prod.Res.Inst.A.R.C.Giza,Egypt., 386.390

Fox , A.E.S.; R.K. Rrabidly ; W.T.S.Marphy ; (2000) Neutral detergent fiber equations in foods and feeds .J. of Anim. Scie. 79: 49-64.

Georing, H. K. and Van Soest, P. J. (1970). Forage fiber analysis (apparatus, reagents, procedures and some applications). Agric. Handbook, No. 37, ARS-USDA, Washington, D C, pp: 397.

Cupta, A. R., Putra, R. C., Saini, M. and Swarup, D. (2007). Haematology and serum biochemistry of Chital (Axis axis) and barking deer (Muntiacus muntjak) reared

Hoek ,A.E . ; A.G. Lemmens;J. W. M. A. Mullink and A.C.Beynen.(1988) .Influence of dietary calcium:phosphorus ratio on mineral excretion and nephrocalcinosis in female rats. J. of Nutiration .118: pp.1210-1216.

Huhtanen, P., Nousiainen, J. I.,Khalili, H., Jaakkola, S. and Heikkilä, T. (2003) relation between silage fermentation characteristics and milk production parameters: analyses of literature data. Livestock Production Science. Science. 81: 57-73.

Ibrahim, F.A , M. E. Ahmed and A. S. Soliman (2008). Cultivation and evaluation of some green forage mixture and its utilization in feeding of lactating zaraibi goats. Egyptian J. Nutrition and Feeds, 11 (2): 329

Ibrahim , F.A.,Soliman , E.S.A.A.Abd E;-Hamid and M.E.AHMED ( 2012) . growth performance and feed utilization efficiency of Rahmany lambs fed some legume and / or grass silages . Egyptian J. of sheep and goats science, vol. 7( 2) . 1 .

Jain, N. C. (1986). Veterinary hematology $4^{\text {Ed }}$ Ed kea and Fibiger Philadelphia

Jalče , D., Varadyova, Z., Laukova, A., Homolka, P. and Jančik, F. (2009). Effect of inoculated corn silage on rumen fermentation and lipid metabolism in an artificial rumen (RUSITEC). Animal Feed Science and Technology. 152: 256-266.

Khampa , S. and Wanapat ,M.(2007).Manipopulation of rumen fermentation with organic supplementation in ruminants raised in the Pakistan, J. of Nutrition , 6(1) 20-27 .
Kaneko,I.H.(1986). Chemical Biochemistry of animals $4{ }^{\mathrm{Ed}}$ Ed Academy Press.,Inc . USA .

Khinizy , A,E,M ; RT.Fouad ; m.m.Mohy El-Deen BVadr ; B.Matter and A.A.M.Fahmy (1997).Effect of feeding whole green maize silage with urea molasses minerals mixture on performance of buffalo calves . Egypt . J.Applied . Sci. 12( 8) .

Kurihara,Y.J.M.Eadie;P.N.Hobson andS.O.Mann(1998).Relationship between bacteria and cillate protozoa in sheep rumen.j.Gen.Microbial,51:267-278.

Lane GT, Noller CH, Clendrander VP, Cummings KR and Harzington, R.B. (1968). Apparatus for obtaining rumino-reticular samples and the effect of sampling location and volatile fatty acids. Journal of Dairy Science, 51: 114-123.

Mahmoud , A.M ; M.M.Bendary ; M.A.Harfoush and G.A.Ramadan ( 1992) . Efeect of Feeding lactating ani,als corn silage on milk production compared with traditional summer and winter rations .Journal of Agriculture Science Mansoura University.

Moawad , R.I.;A.A.Zaki ; M.Marghany and A.A.H.El=Tahan (2001).The effect of replacing cotton plant so;age with maize silage on milk production of dairy cows Egyptian J.Nutrition and feeds , 4: 117-127

Mohammed, M.M., S.M.M. Ahmed and M.M. Bendary (1999). Productive and reproductive performance of growing calves fed rations containing maize silage. Egyptian J, Nutrition and Feeds 2 (Special Issue): 445.

Mohsen ,M.K.;Bassuni, M.I.;Yacout , M.H. and M.A.M.( 2006).Nutritional studies on the use of sugar beet tops silage in feeding lactating goats .J.Agric. Rec. tanta Univ. 32(3:2006.

Mostafa,M.R.R.; M.F.El-Sayes ; M.K.Hhathout and K.E.I.Etmsan (1999) . Nutritional studied on conserved peanut tops as silage and hay using sheep Egyptian J.Nutrition and feed 2 ( Special ISSUE) : 253-263.

Nour , A.M.; A .E.Tag El-Den; S.M.Z. Zahran and M.H.Ahmed(1989).Effect of feeding Agroindustrial by-products on total and differential protozoal counts in the rumen.Third EgyptianBritish Conference Animals Products. Lexandria 7- 10 October,91-101.

Nkosia, B. D., Meeske, R., Langa, T. and Thomas, R. S. (2011). Effects of bacterial silage inoculants on whole-crop maize silage fermentation and silage digestibility in rams. South African Journal of Animal Science. 41 (4): 350-359

NRC, ( National Research Council ), ( 2001). Nutritional requirement of dairy cattle, $7^{\text {th }}$ Rev. Ed National academy Sci. Washington, DC. USA.

Oelker, E. R., Reveneau, C. and Firkins, J. L. (2009). Interaction of molasses and monensin in alfalfa hay- or corn silage-based diets on rumen fermentation, total tract digestibility and milk production by Holstein cows. J. Dairy Sci., 92:270-285.

Rafat, M.A.and M.E.Saleh ( 1962) .Efficiency of feed utilization with dairy buffalos and Cattle . Proceeding of the Sector Animal P roduction Confernes ( March 3-10) Cairo ,Egypt . 
Schroeder , J.W. ( 1996) .Quality forage for maxmum production and return, North Dacota State Univeristy

Saleh,S.A.,M.M.(2007).Effect of using soen gluten feed in growing lambs ration. Egypt. J. Nutrition and feeds , 11(1) : 55-71.

SAS. (2009). SAS/STAT® 9.2 User's Guide, 2nd ed. SAS Institute Inc, Cary, NC USA Soliman, A. A.,Faten. F. Abou Ammou, E.I.Shehata, M. K. Abou Elmaged, and $\mathrm{M}$.

A. Shebl ( 2010). Impact of some feed additives and water intake on Zaraibi goats performance and blood profile fed diets. American Eurasian J.Agric. and Environ. Sci., 7 (1) : 80.

Sony , V.K.andD.D.Sharma (1982) .Influence of levels of concentrate feeding on th microbial population in goat rumen Indian . j.Anim .Sci.,52 (9 ):821-833 in semi-captivity. Vet. Res. Comm., 31: 801-808.

Tovar,I.S., Puchala, R., Sahlu, T., Freetly, H. C. and Goetsch, A. L (2010). Effects of stage of lactation and dietary concentrate level on energy utilization by Alpine dairy goats. J. Dairy Sci., 93: 4818-4828.

Van Soest, P. J. (1970). Environment and forage quality. Proc. Cornell Nut. Conf. Feed Manuf. P 1 Cornell Univ., Ithaca, NY.

Varadyova, Z., Kišidayova, S., Laukova, A. and Jalč, D. ( 2010 ) .Influence of inoculated maize silage and sunflower oil on the in vitro fermentation, ciliate population and fatty acid outputs in the rumen fluid collected from sheep. Czech J. Anim. Sci., 55 (3): 105-115
Vatandoost, M., Danesh M. M. and Vakili, A. R. (2011). Fermentation characteristics, in situ rumen degradation and nutritional value of whole crop barley ensiled with microbial inoculant or ammonium propionate for Lactating Dairy Holstein Cows. Journal of Agricultural Science and Technology (A 1): 1095-1102.

Weichselbaum,(1989).Colorimetric determination of total protein. Anim.J.Clin Pth16:40.

Weiss ,W.P.;Colenbrander V.F.and Lechtenberg V.L.1982 Feeding dairy cow alfalfa hay preserved with ammonia J.Dairy Sci. $65: 121$.

Wheeler, B. (2003 ).Guidelines for feeding dairy animals. Ministry of agriculture and food Government of Ontario Canada.

Wrobel, B. and Zastawny, J. (2004). The nutritive value and aerobic stability

of

big bale silage treated with bacterial inoculants. Proceedings of the 20th general meeting of EGF. Luzern, Switzerland. PP: 978-980.

Yacout , M.H.M. and A.Y.El-Badawi , (2001).Effect of dietary protein level on fattening performance of animal calves .Egyptian .J.Nutrition and feeds 4 (special issue ) $545-556$

Zeid , A.M.M.and I.M.E. Shakweer ( 2011) .Effect of using summer green forage mixture on attending Frisian calves

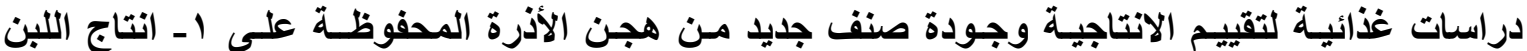

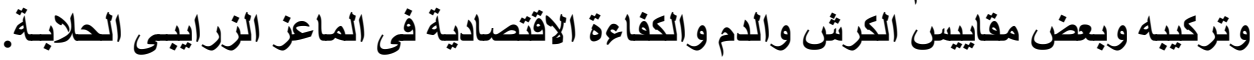

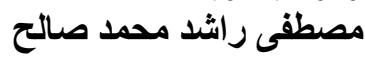 معهد بحوث الإنتاج الحيواني - مركز البحوث الزراعية ـ- دقي - مصر .}

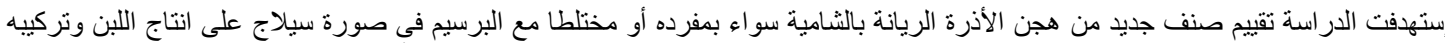

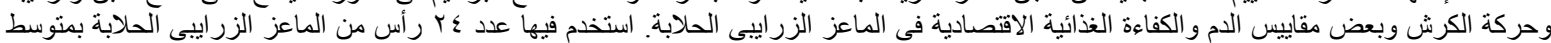

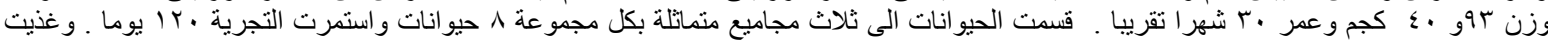

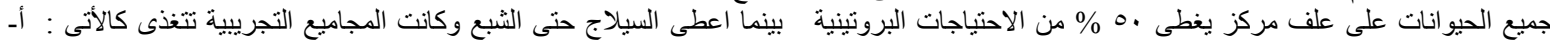

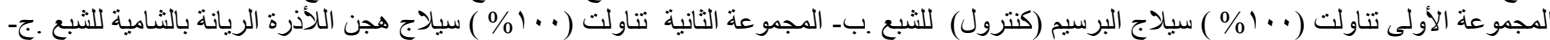

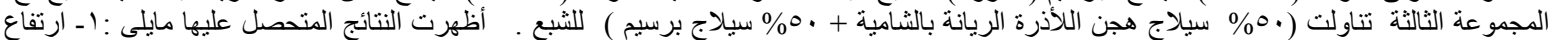

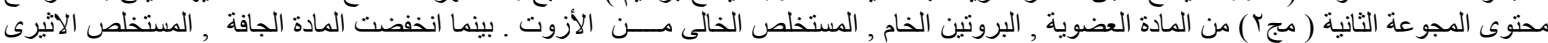

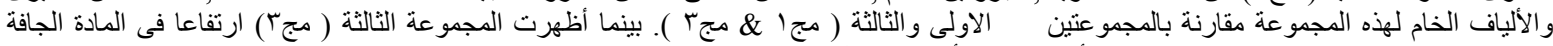

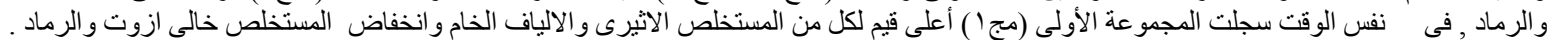

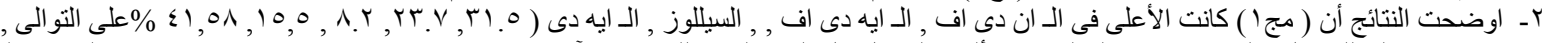

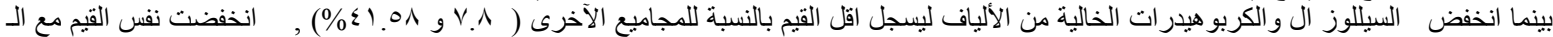

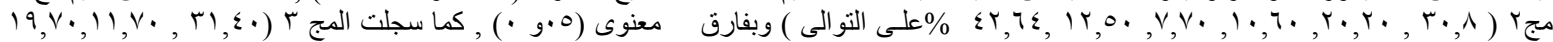

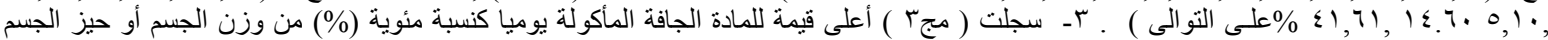

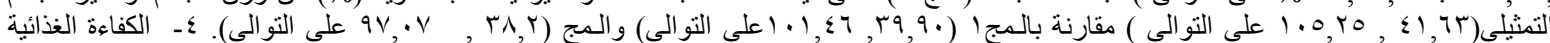

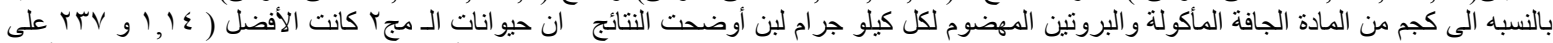

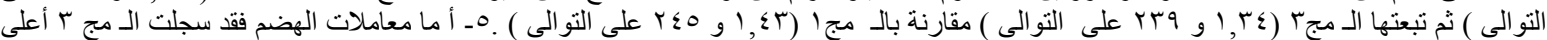

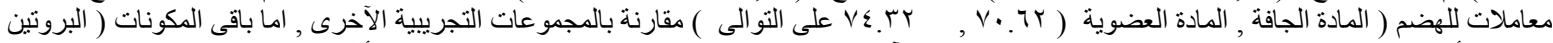

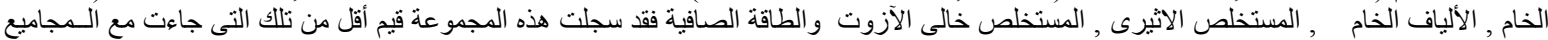

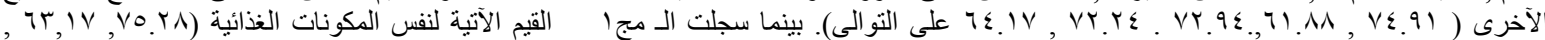

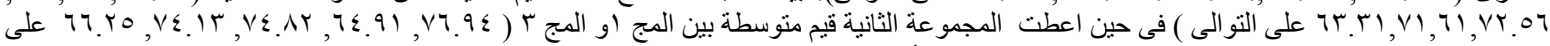

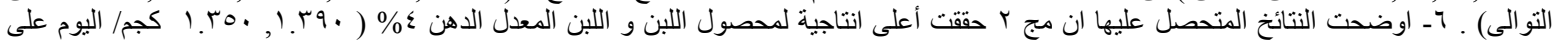

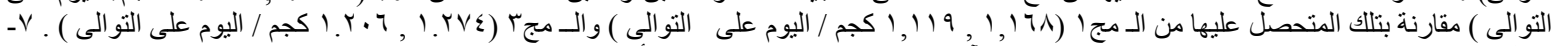

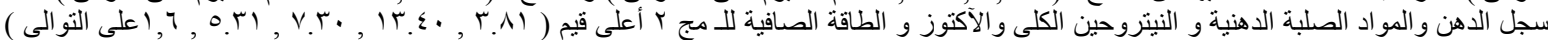

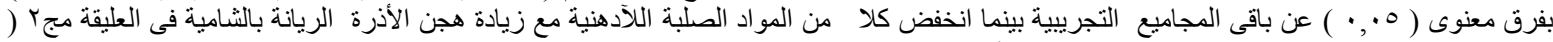

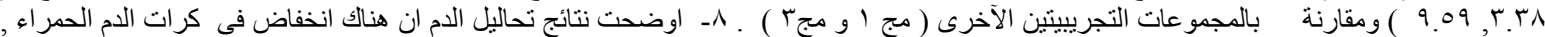

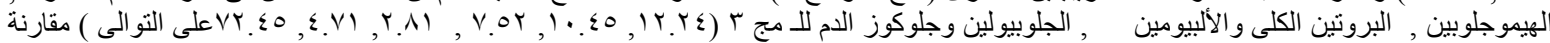

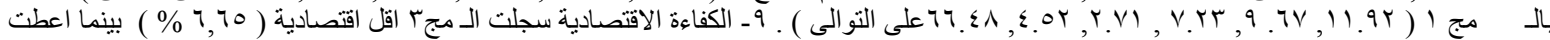

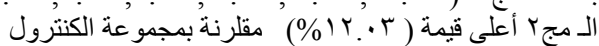

